\title{
Kari Lampikoski
}

\section{Monimuoto-opetus ja tutkimus}

Koulutuksen kehittäjän, suunnittelijan ja toteuttajan näkökulmasta avainkysymykset, joihin tutkimukselta toivotaan vastauksia ovat:

- Keitä tulisi kouluttaa?

- Miksi, minkälaisiin tavoitteisiin, minkälaisin sisällöin?

- Minkälaisilla opetusjärjestelyillä?

- Minkälaisin järjestelmän sisältämin keinoin, välinein ja metodein opetus toteutetaan?

- Miten evaluoidaan tulokset.

Koulutustarve-", opintomotivaatio- ja opintoihin osallistumistutkimukset ovat hyödyksi haettaessa vastauksia ensimmäisiin kysymyksiin. Edelleen esim. kognitiivisen oppimisteorian tutkimuksessa on saatu käytännön sovellutuksia opetuksen tavoiteasetteluun.

Koulutusta koskevat päätökset organisaatioissa sekä yksilötasolla tulisi selvittää aikuiskasvatustutkimuksen keinoin. Tärkeäksi kysymys tulee sen vuoksi, että koulutusfunktio on organisaatioissa viime vuosina muuttunut rakenteeltaan ja toimintamalliltaan.

Strategisen suunnittelun yleistyessä organisaatioissa, koulutus nivelletään yhä selkeämmin organisaation muihin kehittämistoimiin, jotka aiheuttavat koulutustarvetta. Tutkimusote, joka ottaa huomioon tämänkaltaisen koulutuksen ja muiden kehittämistoimien niveltämisen, on hyödyllinen käytännön koulutusta suunniteltaessa. Päätökset koulutuksesta ohjautuvat etenkin kansainvälisesti menestyvissä yrityksissä yhä enemmän menestystekijätutkimusten mukaan, jotka ovat osoittaneet pikemminkin uusia mahdollisuuksia kuin ongelmia koulutuksen lähtökohdiksi. Yritykset pyrkivät kouluttamaan avainhenkilöstöään näiden menestystekijöiden hyödyntämiseksi. Monet yritykset ovatkin strategisessa suunnittelussaan määritelleet henkilöstön koulutuksen strategiseksi kilpailutekijäksi. Koulutusedun tarjonta tullee myös yleisemmin uuden työvoiman houkuttelutekijäksi erityisesti toimihenkilötasolla.
Ongelmallinen jatkuvaa tutkimusta vaativa kysymys on, minkälaisin järjestelmin opetus toteutetaan. Viime vuosina monimuoto-opetus on tullut yhä suuremman kiinnostuksen kohteeksi. Tarpeellisia olisivat koulutuksen taloustieteen piiriin kuuluvat ns. koulutusresurssien allokointitutkimukset. Uusteknologia on viime vuosina tuottanut uusia potentiaalisia opetuksen ja opiskelun ohjauksen välineitä, keinoja ja metodeja, esim. tietokoneavusteisen opetuksen, teleopetuksen, videotex-järjestelmän jne. Esimerkiksi Kanadassa ja Australiassa on jo runsaasti kokemuksia uusien viestintävälineiden, esim. viestintäsatelliittien, teleopetusverkoston ja kaapeli-tv:n käytöstä opetuksessa.

Minkälaiseen opetusteknologiaan Suomen ja yksittäisten oppilaitosten kannattaa investoida? Ennakoidut kustannuslaskelmat ja kustannustehokkuusanalyysit eri opetusteknologisista vaihtoehdoista muodostavat käytännössä tärkeän päätöksentekokriteerin.

Monimuoto-opetusjärjestelmien yleisten piirteiden tutkiminen tuottaa edelleen päätöksentekoa helpottavia faktoja. ICDE (International Council for Distance Education) pyysi jäseniltään jokin vuosi sitten tietoja alan tutkimustarpeista. Tämä IDCE Research Priorities Survey tuotti seuraavia tutkimuksen kohdealueita, jotka soveltunevat suomalaisenkin monimuoto-opetuksen tutkimuskohteiksi:

1. Etäisopetuksen metodiset piirteet

- etäisopetuksen metodit ja käyttömahdollisuudet

- etäisopiskelijoiden sosioekonomiset olosuhteet

- etäisopiskelun prosessien analysointi

- itseopiskelun sosiaaliset vaikutussuhteet

- autonomisen opiskelun piirteet

2. Opintojen loppuunsaattaminen ja keskeyttäminen

- keskeyttämisen ilmiö, syyt ja ilmenemismuodot sekä vaikutukset 
- opiskelutekniset ongelmat

- vertailevat tutkimukset eri maiden välillä

3. Metodit ja mediat

- medianvalintaprosessi

- eri medioiden didaktiset funktiot

- opintomuotojen yhdistely

- opetushenkilön roolit

- medioiden kustannustehokkuusvertailut
- erityisryhmien (kansalliset vähemmistöt, näkövammaiset ym.) opettaminen eri medioin

4. Kurssien suunnittelu ja tuottaminen

- opiskelun tarveanalyysit

- didaktiset aspektit oppiaineiden kehittelyssä. 